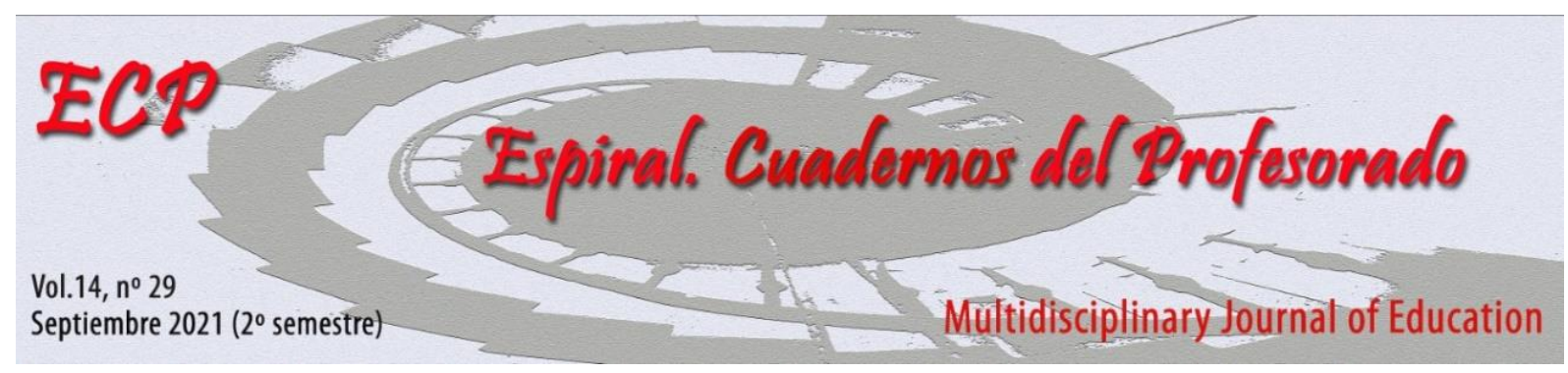

\title{
Sociocultural competence under the scope of 5th and 6th grade EFL Primary school teachers
}

\section{La competencia sociocultural bajo el prisma del profesorado de inglés de $5^{\circ}$ y $6^{\circ}$ nivel de educación primaria}

\author{
Andrés Canga Alonso ${ }^{1}$ y María Alonso Álvarez ${ }^{1}$ \\ ${ }^{1}$ Universidad de La Rioja
}

\begin{abstract}
English as a Foreign Language (EFL) educational curriculum in La Rioja (Decreto $\mathrm{N}^{\circ} 24,2014$ ) fosters the introduction of sociocultural and linguistic competence in EFL teaching. This research focuses on the study of 5th and 6th grade Primary School Education EFL teachers' views on the inclusion of the sociocultural competence in their teaching practice. The study is based on an online questionnaire sent to fifteen teachers from public funded schools in La Rioja. The study revealed that, according to EFL teachers' views, students and teachers showed a positive attitude towards the foreign language and culture. However, teachers noticed a lack of cultural knowledge on their students. Teachers tried to bring culture closer, considering that language and culture are closely linked. The results also purported that teachers adopted a communicative approach in their daily practice, and they preferred to teach cultural topics related to festivities and customs. Further research could be conducted in different grades of primary or secondary education in the same region to provide a complete picture of teachers' perceptions. Students' views would be also worth exploring.
\end{abstract}

Keywords: Sociocultural Competence, EFL, Primary School Education, Culture, Teachers’ Attitudes.

\section{Resumen}

El currículo educativo de Inglés como Lengua Extranjera (ILE) en La Rioja (Decreto No24, 2014) fomenta la introducción de la competencia sociocultural y lingüística en ILE. Esta investigación se centra en la competencia sociocultural desde la perspectiva de los docentes de ILE en quinto y sexto de educación primaria. El estudio se realizó mediante un cuestionario online respondido por 15 docentes de centros sostenidas con fondos públicos de La Rioja. Los resultados indican que, desde la perspectiva del profesorado, tanto ellos mismos como sus estudiantes muestran una actitud positiva hacia la lengua y cultura extranjeras, considerando que lengua y cultura están estrechamente unidas. Sin embargo, se percibe una falta de conocimiento cultural por parte de los estudiantes. Los resultados muestran que el profesorado adopta un enfoque comunicativo optando por enseñar temas culturales relacionados con festividades y costumbres. El presente estudio abre el camino para futuras investigaciones, en diferentes niveles de educación primaria y/o secundaria en la región, proporcionando una imagen completa de las percepciones del profesorado, teniendo en cuenta, también, las opiniones de los estudiantes.

Palabras clave: Competencia Sociocultural, Inglés como Lengua Extranjera, Educación Primaria, Cultura, Actitudes del Profesorado.

Fecha de recepción: 19/12/2020

Fecha de aceptación: 11/07/2021

Correspondencia: Andrés Canga Alonso. Universidad de La Rioja, Spain Email: andres.canga@unirioja.es 


\section{Introduction}

Culture and sociocultural aspects, which have been traditionally overlooked in English as a Foreign Language teaching (EFLT) until the 1990s (Kramsch \& Zhu, 2016), have gained importance in recent decades fostered by the policies of the European Union, specifically by the Common European Framework of Reference for Languages (CEFR, 2001). Moreover, important related concepts such as pluriculturalism have been recently promoted in the CEFR Companion Volume (Council of Europe, 2020). Therefore, research on the introduction of sociocultural features in the teaching of English as a foreign language has emerged in recent decades (Méndez García, Castro Prieto, \& Sercu, 2005-6; Demircioğlu \& Çakır 2015). However, there is a scarcity of research in Spanish Primary School Education (PSE) and particularly in La Rioja where the present study has been conducted. This paper, therefore, delves into teachers' attitudes towards the teaching of culture in 5th and 6th grades of PSE La Rioja (Spain). The paper provides the reader with an overview of culture together with its introduction in EFLT. The role of culture in the educational curriculum is also reviewed. We finish this theoretical framework by exploring teachers' perceptions of culture. The methodology followed in the study and its main findings are, then, presented and discussed. Finally, we point out some lines for further research to overcome its main limitations.

\section{Theoretical Framework}

\section{Culture, sociocultural competence}

Richards and Schmidt (2010, p. 151) defined culture as "the array of practices, codes and values which characterize a country or region. They include pieces of art of all classes: literature, music, painting, sculpture, etc". On the other hand, sociocultural competence is the result of the development of the "linguistic competence" which makes reference to the linguistic knowledge native speakers have and which allows them to build up and understand sentences in their language (Chomsky, 1965).

In the 1970s, several studies portrayed that Chomsky's model was inaccurate because it only considered the grammatical side of language, leaving aside its actual use and guiding principles. Thus, the umbrella term "communicative competence" came into play as it encompasses linguistic and contextual elements (Hymes, 1971), paying special attention to the pragmatic dimension of language.

The notion of communicative competence was highly developed during the following years. In this respect, as argued in Galindo Merino, Canale and Swain distinguished among four different sub competences inside the concept of communicative competence: grammatical, sociolinguistic, discursive, and strategic $(2005$, p. 433). This model shows that it belongs to the sociolinguistic competence.as the message appropriateness is influenced by the participants, the context, and the purpose of the communicative act. Hence, this adequacy deals with social and pragmatic rules (Galindo Merino, 2005, p.433).

Despite Canale and Swain's approach was the most influential in the USA (Byram, 1997, p.9), European scholars such as van Ek introduced the model of 'communicative ability' (van Ek, 1986, p. 35). This model included six competences (linguistic, sociolinguistic, discourse, strategic, sociocultural, and social). They are not discrete, but "different elements of one concept" (van Ek, 1986, p. 36). For the purpose of this study, we will follow van Ek's definition of the sociocultural competence, understood as "the use of a particular reference frame which is partly different from that of the foreign language learner; sociocultural competence presupposes a certain degree of familiarity with that context" (1986, p.35). This definition is reinforced in Ayora Esteban's (2017) description since the knowledge of cultural and linguistic forms, routines, language and social conventions and non-verbal behaviours in a foreign language, as well as the speaker's ability to use this knowledge in different communicative situations in order to attain the intended communicative function are crucial in EFLT.

Nowadays, the concept of sociocultural competence itself has gained relevance in the educational field. It should be also noted that as will be argued in the next section, the CEFR (2001, p.168) and the CEFR Companion Volume (2020 p.30) state the need of students to get a plurilingual and pluricultural competence which can be achieved by means of the development of Intercultural Communicative Competence (ICC) (Byram, 1997). The former will be achieved by students, according to the CEFR 
(2001), when they acquire intercultural savoir-faire skills (Canga Alonso, 2020) and, at the same time, they reach the ability to identify and solve possible culture-related misunderstandings and stereotypes by relating their source culture with the target one. Hence, as Canga Alonso (2020) argues, the sociocultural aspect should be included in EFLT.

Once we have presented the notion of culture, as well as the development and definition of the concept of sociocultural competence, the following section explores the inclusion of cultural contents in EFLT.

\section{Culture in EFLT}

Culture and language are closely intertwined as they reflect society (Ayora Esteban, 2017). For this reason, linguistic features cannot be separated from their sociocultural aspects. To communicate effectively and to learn and master a language, it is essential to have a wide knowledge about its culture, society, cultural conventions, and reality. Hence, Ayora Esteban (2017) claimed that the sociocultural content in the language classroom should be included in teaching materials to avoid its segregation. Martínez Iglesias (2009) also remarked that foreign language teachers should have in mind that the main objective is to teach how to communicate with the members of the foreign language community.

Traditionally, grammar-related contents occupied the leading role in foreign language teaching, leaving aside culture and drawing a clear distinction between grammar and the sociocultural aspects, which were taught separately. Consequently, optimal communication between native speakers and foreign language learners was not reached because the former lacked (inter)cultural competence. In this vein, Neuner (1996) argued that there was an evolution in the way that culture has been treated in EFLT. Firstly, only Big C was introduced in foreign language teaching with the Grammar Translation Method. This type of culture deals with every kind of artistic manifestation of a given culture (music, painting, sculpture, architecture, etc.) and it is taught independently from the rest of class contents. Later, the Direct Method focused on the study of realia, again emphasizing the 'Big C', above all other cultural features (Neuner, 1996, p.235).

With the arrival of Fascism in Europe, the introduction of sociocultural features in the foreign language classroom was intended to praise the native national and political values and to underestimate the culture, society and relevance of the foreign countries (Neuner, 1996, p. 235). In the Cold War, the pattern was very similar to that applied during Fascism (Neuner, 1996, p. 235). The turning point arrived in the sixties with the Audio-Lingual Method, more related to Pragmatics. This approach introduced cultural aspects implicitly within the rest of materials to portray the foreign language in everyday situations and contexts. Besides, it gives relevance to oral communication skills by means of drills, memorization and repetition of patterns and short dialogues (Alemi \& Tavakoli, 2016).

The most recent approaches related to sociocultural competence are the communicative and intercultural ones. The communicative approach focuses on comprehension and production tasks. It is, as House (2011) points out, a learner-centred approach in which students communicate in authentic ways. As for the teachers, who act as facilitators or guides, they have as their main goal that of fostering communicative competence among learners. Therefore, pair group and groupwork exercises should be included (House, 2011) in EFLT as well as practical activities (e.g. role play) since they encourage learners to experiment, use the language, and have real contact with it.

From an intercultural approach, learners become interculturally and linguistically proficient and develop "their critical cultural awareness together with the skills to understanding and successfully interacting with people from other cultures" (Abdalla, 2017, p.54).

As abovementioned, currently the sociocultural competence plays an essential role in foreign language teaching. The CEFR and CEFR Companion Volume (2020) have included the sociocultural knowledge of the foreign language as one of the essential competences that a learner needs to attain to reach different levels of proficiency in the target language. The CEFR specifies that sociocultural knowledge needs special attention because of the biased perspectives and stereotypes that learners may have when they begin to learn a language (2001, p.102). According to the CEFR (2001, p. 102), the sociocultural competence includes 'everyday living; living conditions; interpersonal relations; values, 
beliefs and attitudes; body language; social conventions; and ritual behaviour'. These seven issues should be the linchpin for the creation of materials whose aim is to focus on communicative language competences. Intercultural Communicative Competence (ICC), defined by Byram (2015, p.38) as "the ability to meet and engage successfully with people of another social group"; and plurilingual and pluricultural competences, which are understood as the "ability to use languages for the purposes of communication and to take part in intercultural interaction, where a person, viewed as a social agent has proficiency, of varying degrees, in several languages and experience of several cultures" (CEFR, 2001) should be also approached in EFLT contexts.

Overall, foreign language teachers, bearing in mind the aforementioned competences, should also be aware of the current cultural diversity that can be encountered in their classrooms. As language learning needs to incorporate the intercultural communication capability, foreign language teachers must foster the intercultural competence in their students (Guryanov et al., 2019). Besides, it is important that they show a positive attitude to the foreign culture. In this way, they will contribute to encourage the respect for the foreign culture and its peoples. The role of sociocultural education at these stages is to provide the learner with information and mechanisms to avoid and overcome misunderstandings caused by the lack of knowledge about the target culture. In this sense, as Vetrinskaya and Dmitrenko (2017, p.38) point out, "there is an urgent need for students to prepare for effective intercultural contacts at the level of everyday interpersonal communication." Furthermore, when a teacher introduces the sociocultural aspects of a given community, it is also essential to take into account that learning cultural aspects should not imply that students should forget their own culture and lifestyle, but their own cultural knowledge should be the basis to build up a better and thorough understanding and awareness of the foreign culture.

Having discussed the role of culture in EFLT, the following section explores the inclusion of culture in the EFL curriculum in La Rioja, as well as the relevance it gives to the sociocultural competence.

\section{The representation of culture in the EFL curriculum in La Rioja}

Cultural aspects within EFL are present in PSE curriculum in La Rioja, as it is based on the CEFR (2001). As stated in the introduction to the curriculum (Decreto $\mathrm{N}^{\circ} 24,2014$ ), foreign language learning is of great relevance for education, because it allows students to communicate in an increasingly plurilingual and pluricultural contexts. Thus, it is stated that even in the introduction to the contents and assessment criteria of the subject, culture has a key role. This fact is an indicator of the central role of culture, and therefore of sociocultural aspects, in the field of foreign language teaching, unlike it happened in the past as illustrated in the previous section.

In this vein, the PSE curriculum takes cultural aspects into consideration and purports that the last two grades of primary school education should provide young EFL learners with tools to understand and comprehend the culture/s involved in their learning process. In fact, cultural representations are presented, i.e. contents and assessment criteria, in each of the four blocks included in the curriculum (comprehension of oral texts, production of oral texts, comprehension of written texts and production of written texts). Throughout the whole document, cultural aspects are related to identify the different English-speaking countries and students' interest to establish contact with children from these places. At the same time, rules of courtesy, daily activities, behaviour and children's lifestyle in Englishspeaking countries are portrayed. Special attention is also paid to the similarities and differences between students' native culture and the foreign language culture. Festivities such as Halloween, Christmas, St Patrick's Day, Valentine's Day are also present, as well as traditional tales and songs (Decreto $\left.N^{\circ} 24,2014\right)$.

The present section has explored the treatment of culture in the PSE curriculum in La Rioja. We, now, move to provide the insights from previous research on teachers' cultural perceptions.

\section{Teachers' perceptions on culture in EFLT}

The existing body of research on teachers' perceptions on the importance of teaching cultural aspects in EFL classrooms to foster students' intercultural competence in Spain (Clouet, 2012; Méndez García, et al., 2003; Méndez García et al., 2005-6; Pérez García et al., 2017), and worldwide (Atay et al., 2009; Young \& Sachdev, 2011; Demircioğlu \& Çakır 2015; Cheewasukthaworn \& Suwanarak, 2017, Bal 
\& Savas, 2020) suggests that teachers and students generally adopt positive attitudes towards the intercultural and sociocultural competences, except for Méndez García et al. (2005-6) which reported students' negative attitudes towards the foreign culture and reliance on stereotypes to approach it (Méndez García et al., 2005-6; Méndez García et al., 2003).

Regarding teachers' knowledge about culture, most of the studies concurred that teachers were aware of the role of culture in Foreign Language Education (Atay et al., 2009), but they had a superficial knowledge of concepts such as ICC (Young \& Sachdev, 2011). In this sense, as Bal and Savas (2020) explained, only few teachers from their research were aware of all dimensions forming intercultural competence. Besides, despite their good predisposition, they often paid more attention to cultural topics related to the "small c", e.g. lifestyle and customs (Méndez García et al., 2005-6). Finally, most of the teachers agreed with the fact that cultural aspects were not reinforced enough in the FL curriculum. They also emphasized the need to introduce a higher number of sociocultural activities in the teaching practice, as well as to encourage research on the relevance of culture when learning (and teaching) a foreign language.

In the light of the reviewed literature, this study aims to contribute to this growing area of research by exploring teachers' perceptions in La Rioja, limiting the scope of the investigation to the latest grades of PSE. This decision has been made to contribute to widen the corpus of studies related to teachers' views on the influence that culture and intercultural competence exert in EFL classrooms.

To our knowledge, despite the increasing number of studies carried out in the field of ICC, there is still a scarcity of research in the academic field as only three studies have addressed teachers' views on intercultural competence. Méndez García et al. (2005-6) explored teachers' perceptions regarding cultural learning in seven European countries (424 participants). Clouet (2012) analysed attitudes to culture in secondary 20 school teachers and 390 students in the Canary Islands, and Pérez García et al. (2017) conducted research with 59 PSE teachers in Córdoba. However, we have found no evidence of previous research on teachers' insights towards the foreign language and culture in the region of La Rioja as well as their views on their students' attitudes towards the same topic.

Considering the reviewed literature, this study revolves around EFLT teachers' attitudes towards the foreign language and culture in the last two grades of PSE (5th and 6th) in the region of La Rioja. The study also examines teachers' thoughts about their students' perceptions towards the foreign culture as well as teachers' approaches in regard with their choice of extra-materials and resources aimed to foster the sociocultural competence.

We aim to answer the following research questions:

RQ1: What are 5th and 6th grade EFL teachers' views on their students' approach towards the foreign language culture?

RQ2: What are 5th and 6th grade EFL teachers' perceptions about the teaching of the foreign language culture?

RQ3: Do teachers' attitudes towards the foreign language culture influence their choice of sociocultural contents in their lessons?

Once we have discussed the theoretical notions in which this paper is grounded, the following section presents the methodology followed to conduct the research.

\section{Methodology}

\section{Participants}

This study has been carried out with 15 EFL teachers from the 5th and 6th grades of PSE. The respondents, who were native Spanish speakers, worked in different public-funded schools located in the Region of La Rioja (Spain). The teachers answered an online questionnaire. We used an online format to preserve the participants' anonymity and facilitate its fulfilment and submission.

We delivered the survey to thirty-six teachers. They were given ten days to fill it in (February 21, 2020- March 2, 2020). At the end of this phase, there were fifteen answers to the questionnaire (41.67\%); 
consequently, it should be considered that the scope is limited, but quite similar in size as Clouet (2012), despite La Rioja is less populated than the Canary Islands.

\section{Instruments}

The participants were sent a link via email to gain access to an online questionnaire which was edited in a google.doc document. It was written in Spanish to be easier and quicker for the teachers to fill it in. It is valid and reliable because it was adapted from a similar study with an international scope conducted in the Spanish region of Andalucía at the beginning of the 21st century by researchers from CULTNET (Méndez García et al., 2005-6). Some questions remained the same as the ones in the aforementioned investigation. Items 13 and 16 in part 1 and statements $1,7,8,10,23$, in part 2 (see appendix 1) were slightly changed, and new queries were added to adapt the study to its educational context part 1: 3, 6, 7, 8, 9, 10,17, 18, 19, and items $12,14,16,17,18,19,20,21,22$, in part 2 (see appendix 1). The last section of the questionnaire is completely original (see Appendix 1). Dr Méndez García from CULNET have us revised our questionnaire to give us feedback on its three different sections.

Each of these three sections aimed to answer our research questions mentioned. Thus, Part 1, made up of nineteen questions, aimed to discover students' attitudes towards the foreign language and culture through their teachers' visions. Section two (twenty-three items) was addressed to investigate the inclusion of culture in the teaching practice, whereas the last part of the questionnaire included five questions to explore teachers' perceptions about the teaching of foreign language and culture.

\section{Procedure and Data analysis}

As abovementioned, on Feb 212020 we submitted the questionnaire to the 36 PSE EFL teachers we had previously contacted and accepted to take part in the research. Participants were asked to respond to the close questions designed for sections one and two, using a 5-point Likert scale ranging from 'never' to 'always'. A 'yes-no' question (e.g. My students frequently talk about English-speaking countries different from the USA and the UK) and a 'positive-negative' one (e.g. "On average, my students' perceptions regarding the foreign culture are") were also incorporated.

Data analysis is based on the answers obtained out of the Likert scale questions. The findings will be presented by means of percentages and pie graphs. Qualitative explanations will be also provided based on our informants' answers to section 3 (see Appendix 1).

Once the methodological process has been explained, the following section delves into the main findings of present study.

\section{Results}

As for students' feelings about the difficulty of learning EFL (RQ1: What are 5th and 6th grade EFL teachers' views on their students' approach towards the foreign language culture?), the results showed that they sometimes (60\%) found English as a difficult language to be learnt.

In regard with their degree of motivation and eagerness to learn the foreign language (see Figure 1), the participants overall agreed that their students had a good predisposition to study the language. $73.3 \%$ of those who were interviewed indicated that their students were usually motivated to study the new language, and more than a half (53.3\%) stated that their pupils were usually eager to learn it.

When inquired whether their students showed a positive attitude towards the foreign language, most of our informants $(93.3 \%)$ indicated that their students showed a positive approach towards the language they learnt. In this way, the higher the attitude, the more eager and motivated young learners would be. In addition, it seems that teachers did not think that their students were already biased by stereotypes about the foreign language that were present in the media. In fact, $53.3 \%$ of the surveyed pointed out that learners sometimes had previous stereotypes about the foreign culture and only $20 \%$ of the teachers reported that they were usually influenced by previous ideas from the media. 


\section{Figure 1.}

My students are motivated to learn the foreign language.

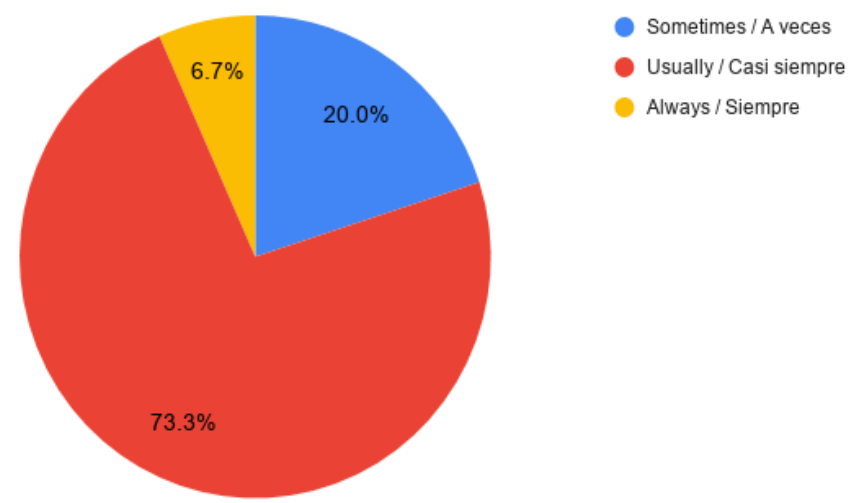

As for the usefulness of EFL, our outcomes indicated that most of the teachers considered that their students found English useful. $40 \%$ of them agreed that they always considered it to be useful and the same percentage reported that it usually happened. In the same vein, most teachers stated that their students regarded the foreign language as a tool for communication.

Once the approaches towards the foreign language have been tackled, students' feelings and awareness in regard with the foreign culture will be portrayed. As for young learners' cultural awareness, our data reported diverse opinions. $40 \%$ of the teachers surveyed thought that their pupils sometimes purported a certain degree of cultural awareness, while $33.3 \%$ of them believed that they were usually aware of the foreign language cultural features.

Concurrently with students' perceptions about the foreign language, they showed a positive attitude towards the culture because most of them rarely rejected different traditions and customs. Besides, from their teachers' views, young learners were also attracted by the foreign language culture. They mostly agreed on the fact that the positive conceptions about the foreign language country and people came from inside their EFL lessons rather than from the outside.

Moving to the students' preconceived ideas on the countries where the foreign language is spoken, there is a correspondence in the teachers' answers about their pupils' perceptions towards the foreign country, because nearly $90 \%$ of them concurred with the fact that students usually showed a positive attitude to the foreign country.

Despite the positive mindset, the results showed that there was a lack of knowledge about other English-speaking countries, not being able to distinguish the heterogeneity of English as an International Language (EIL). Furthermore, they felt more interested in the United States than in the United Kingdom because they associated the former with stereotypes and preconceptions that had negative connotations because they might relate the UK with strict manners and rigidity.

In regard with the results for RQ2 (What are 5th and 6th grade EFL teachers' perceptions about the teaching of the foreign language culture?), most teachers agreed with the idea that language and culture were intrinsically linked. Besides, some of them mentioned that cultural awareness could help children adopt a more tolerant attitude towards people from other countries and cultures. Finally, four informants pointed out that the introduction of cultural aspects reinforced their belief that the language was a reality and not a construct as it may happen in textbooks.

The second question of this section was: 'Which limitations do you find with the inclusion of the foreign culture in your teaching?' Six of them regarded time constraints as the main drawback because, according to their views, the educational EFL curriculum was too tight, becoming an obstacle for the correct inclusion of culture in their sessions. One teacher explained that it was very difficult to teach a culture from the distance and that it would be much better to offer the students a real immersion. Another informant highlighted the lack of teaching continuity within the same levels of education or the lack of interest that some students showed towards the foreign culture. To solve this problem, one of them argued that it would be sensible to find a place of interest for the students. 
In the third inquiry related to teachers' perceptions on foreign language teaching (see Figure 2), they were asked for the easiest cultural aspects to be taught. The answers were quite homogenous because nine of them agreed on the fact that the easiest cultural features to teach were those related to traditional customs and festivities.

\section{Figure 2.}

What cultural aspects do you think are easier to teach in the classroom?

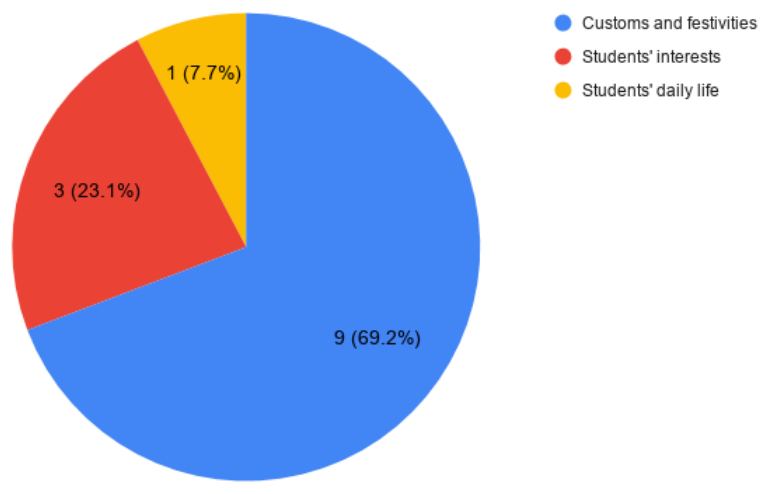

Regarding the type of culture-related facts they tended to include in their teaching practice, the teachers suggested a wide range of answers. Six of them tried to introduce topics related to sports, music, famous people, or the monarchy. One teacher reported that he/she tended to introduce news from the radio and/or newspapers from English-speaking countries and three more that they usually introduced all kind of cultural elements that may attract their students' attention. Besides, other answer was related to famous people that had visited Spain, natural disasters that happened when the lesson was taking place or current festivities. Finally, four of them concurred with the fact that they brought to the classroom news that they heard in their homes or watched on TV, such as Brexit, Donald Trump or the Super Bowl.

Finally, they were asked whether they would change some aspects of the curriculum as far as the time devoted to culture in the foreign language classroom is concerned, $42.9 \%$ of them would change the curriculum, but they concurred with the idea of extending the time assigned to EFLT in the educational curriculum. $21.4 \%$ highlighted the importance of lengthening the working period of the language assistants. In addition, two of them pointed out that they would boost immersion programmes within primary schools. Another informant suggested that he or she would change teaching methodologies and eliminate textbooks. Finally, one respondent argued that no changes were needed.

In order to answer RQ3 (Do teachers' attitudes towards the foreign language culture influence their choice of sociocultural contents in their lessons?) teachers were inquired to reflect on the selection of materials they tended to use in their teaching practice

The first question focused on the role teachers gave to certain cultural topics (e.g. traditions) in their teaching practice. In this respect, we found that lifestyle and daily life were the most recurrent topics, followed by traditions, tourism and hobbies, history and geography, and education. On the other hand, areas related to literature, gastronomy, politics and society, values and beliefs and different ethnic and social groups were usually set apart from the teaching contents.

As for the introduction of personal culture-related experiences on the part of teachers, $80 \%$ of them asserted that they always brought their own experiences to their teaching context and $20 \%$ pointed out that they usually did so.

We also wondered if they commented on what they read or heard about English-speaking cultures. $46.7 \%$ teachers indicated that they always showed these materials in class, $33.3 \%$ pointed out that they usually did it. Similarly, they were inquired whether they talked about the most remarkable aspects about the foreign language culture and their responses were very similar to those of the previous statement. 
Besides, they were asked whether they normally commented on cultural aspects that had already appeared in their teaching materials (textbooks). In this respect, their answers were balanced since 46.7\% of the teachers answered that they always proceeded like that and the same percentage indicated that they usually accounted for cultural aspects from already seen materials.

A relevant question to explore the relationship between teachers' attitudes towards the foreign language culture and their choice of EFL materials was related to the frequency in which they used multimedia resources to introduce cultural aspects. Their replies revealed they mostly relied on multimedia resources from their teaching materials to support their explanations since $46.7 \%$ of the respondents usually focused on them and $40 \%$ always did so. Our data also presented teachers' willingness to introduce anglophone speakers and realia in their sessions.

They were also asked about the implementation of interactive activities to reflect real intercultural situations in the classroom and the results showed a positive tendency to introduce these issues in their teaching practice. Therefore, we can conclude that teachers who tried to make their students identify with foreign people in a foreign culture adopted a positive approach to culture.

Teachers were also inquired whether they encouraged their students to talk about their personal experiences in their EFL classroom interactions, $53.3 \%$ of them always encouraged them and $46.7 \%$ indicated that they usually supported them.

\section{Figure 3.}

I encourage my students to share their personal experiences and knowledge about foreign culture.

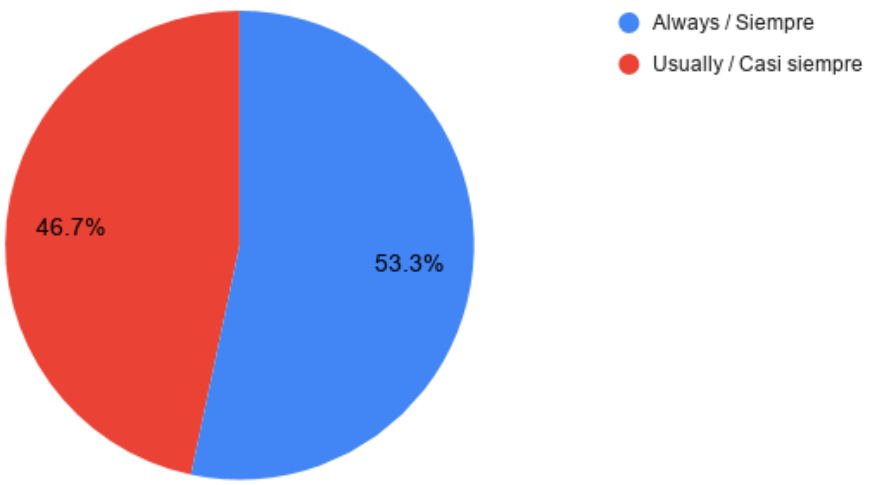

Similarly, $26.7 \%$ of teachers indicated that they always introduced cultural items that only existed in the foreign language and did not have an equivalent in their source culture, so they were completely new for their students.

We also wanted to know whether our informants introduced World Englishes in their teaching practice. Their answers were diverse, ranging from $33.3 \%$ of them who sometimes attempted to do so, to $6.7 \%$ who never introduced them. One of the most illustrative questions was if they tried to make their students understand diversity, $86.7 \%$ of them pointed out that they always introduced the importance of diversity in their teaching practice.

The last two questions offered the most surprising answers of the questionnaire. The first one asked teachers whether they presented cultural aspects in parallel with the rest of the curricular content. In this vein, the predominant answer was "always" with a $53.3 \%$, followed by "usually" represented by a $33.3 \%$. Nevertheless, the following question inquired them the opposite: if they integrated cultural contents into the rest of the programme. They indicated that they mostly included cultural features in their sessions. Hence, there seems to be a contradiction between the two set of answers.

\section{Discussion}

As for the first research question (What are 5th and 6th grade EFL teachers' views on their students' approach towards the foreign language culture?), our data revealed students' positive attitudes towards the 
foreign language culture and people, according to their teachers' perceptions. This outcome may also be linked to the assumption that teachers did not consider that their students were biased by stereotypes from the media. This positive attitude towards English is reinforced by the teachers' assertion that students found EFL learning useful as it is a powerful tool for communication in our globalised world. These findings partly contradict Méndez García et al. (2005-2006) as their sample of teachers believed that their students had negative approaches towards foreign language people. The increase of pluricultural background of PSE learners may account for this change of perspective. Besides, their study was piloted with secondary school teachers and teenagers may have different views of English as opposed to young learners (PSE) who might be more engaged to learn the FL. Their study was implemented in a more densely populated and diverse region (Andalucía) than La Rioja, so if we had surveyed a higher number of teachers our results may have differed. Finally, EIL and globalization are very influential nowadays and young learners may view English as a window to socialization. CLIL programmes may also favour this positive attitude. However, these assumptions are mere speculations and further research is called to test these two hypotheses.

Our findings also outlined that, according to their teachers' views, young EFL learners lacked knowledge about the different countries where English is spoken. These results concurred with Méndez García et al. (2005-6) and Clouet (2012). In fact, Clouet (2012, p.329) pointed out that: "it seems that their knowledge of the foreign culture only revolves around daily life and routines, food and drink, and some aspects of youth culture." A possible explanation for this outcome might be that the easiest topics to teach, according to our informants, were those related to traditions, festivities, lifestyle, and habits. These topics are also included in the PSE curriculum to foster ICC (see section Culture in EFLT in this paper). Similarly, some textbooks include the topic of festivities at the end of each unit under the heading of "Festivals" (Casey, 2017; Read \& Ormerod, 2018).

RQ2 aimed at exploring 5th and 6th grade EFL teachers' perceptions about the teaching of the foreign language culture. Our data purported that language and culture are inseparably linked and, therefore, teachers considered culture to be essential for EFL, which concurs with Bal and Savas (2020), who observed that middle and high school Turkish teachers foregrounded the link between culture and language. The results of this study illustrated that the introduction of culture was closely related to the concept of tolerance since sociocultural aspects foster the understanding of diversity. Hence, it seems reasonable to believe that the main goal of introducing culture in the EFL classroom is to develop a broadminded ethos in the children. On the contrary, Demircioğlu and Çakır (2015) purported that Turkish teachers set as their main objective the task of helping students to attain some practical knowledge.

As for the teaching of the foreign language culture, our teacher informants pointed at time and the fixed educational curriculum as the main limitations for the introduction of culture in their teaching practice. They showed a positive predisposition to teach culture because they would change the curriculum to have more time. Similarly, Demircioğlu and Çakır (2015) supported the idea that the sociocultural aspects of the language should be emphasised in EFL teaching.

RQ3 targeted at the influence of teachers' attitudes towards the foreign language in their choice of sociocultural contents for their sessions. The prevailing impression was that teachers tried to bring culture closer to their students, maybe due to a new tendency of giving prominence to sociocultural contents in EFL classrooms. Thus, teachers acknowledged that they tended to introduce their own experiences related to the foreign culture, as well as their comments on some international news. Concerning the introduction of foreign people and realia, they generally tried to include both elements in their sessions. Hence, it could be asserted that they could have been introduced since teachers may have lived in foreign places, visited them as tourists or met foreign people.

Our respondents also revealed that they encouraged students to talk about their own culture-related experiences in their sessions. In this vein, although teachers' experiences were still very present in their cultural teaching practice, the emergent tendency of students' experiences that Méndez Garcia et al. (20056) noticed seems to have been confirmed in our study since, in the last decades, EFL pedagogies have focused on the communicative approach and sociocultural aspects have gained relevance after the 
publication of the CEFR (2001), the PSE EFL curriculum in Spain (Decreto No 24, 2014), and the CEFR Companion Volume (2020).

Finally, Clouet (2012) and Atay et al. (2009) stated a clear distinction between language and culture. Nevertheless, there is a contradiction in our teachers' responses as they indicated that they integrate cultural aspects into the rest of materials, and they separate them as well. So, it is hard to come to a solid conclusion. However, its origin may reside in a misunderstanding and, therefore, in future investigations, the item should be reformulated with a wider sample of informants.

\section{Conclusions}

The main aim of the study was to provide a panorama of how the sociocultural aspects of the language were dealt with in the highest grades of primary school education in La Rioja (Spain) as well as the approach that teachers had towards culture. In this sense, the investigation has shown that, on their teachers' eyes, students showed a positive attitude towards the foreign language and people, but they lacked some cultural knowledge which led them to sometimes rely on stereotypes. Regarding teachers' attitudes, they showed a positive approach towards the integration of culture considering that culture and language were closely related. They believed that presenting cultural aspects may help to foster their students' understanding of diversity. Besides, they tended to adopt a communicative approach with interactive activities. For them, the easiest cultural topics to teach were the ones related to customs and festivities. However, some of them also agreed on the fact that introducing aspects that matched with the students' point of interest was sensible. Finally, they also argued that the main limitation to the introduction of sociocultural aspects in the teaching practice was the lack of time and the fixed structure of the curriculum. Therefore, it would be supportive to increase the working hours of language assistants.

Our findings contribute to make readers aware of the need to incorporate sociocultural aspects in EFLT. However, the scope of this study is limited in terms of the sample because the instance of fifteen teachers does not allow us to come with ample generalizations as it may not represent the whole teaching community of La Rioja. Notwithstanding the relatively limited sample, this work offers valuable insights into the way culture is treated in EFL and its relevance for pre-service teacher training since it reveals some necessities of improvement in regard with the reinforcement of sociocultural competence in EFLT.

Further research in this field would be of great help to explore the treatment of sociocultural traits of English in EFL classrooms, as well as the insights that students have about it. In future investigations, it might be possible to broaden the sample and the grades to obtain the whole picture of PSE teachers' cultural views in EFLT in La Rioja. Continued efforts are needed to make foreign language more accessible to PSE students, as it is inherently linked to culture.

Authors' contribution: Conceptualization, A.C.A y M.A.A. Methodology, M.A.A..; analysis, A.C..A y M.A.A.; Paper writing: M. A, A, writing, revision and edition, A.C.A.; supervising, A.C.A.

Financial support: This research is framed under a research Project funded by FEDER Spanish Ministry of Science and Innovation-Research State Agency under Grant PGC2018-095260-B-100.

Acknowledgements: We are grateful to the Primary School teachers who took part in the study and Dr M Carmen García (Universidad de Jaén) who carefully revised our questionnaire before its implementation.

Conflict of interest: The authors declare that there is no conflict of interest.

\section{References}

Abdalla, A. H. (2017). An Investigation into the Benefits of the Intercultural Approach to EFL Learning and Teaching: A Case Study of Taif University, KSA. Journal of Language Teaching and Research, 8(1), 5263.

Alemi, M., \& Tavakoli, E. (2016). Audio Lingual Method. In 3rd International Conference on Applied Research in Language Studies. https://www.researchgate.net/profile/Maedeh_Alemi/publication/293731529_Audio_Lingual_Method/li nks/59c643de458515548f3268ec/Audio-Lingual-Method.pdf 
Atay, D., Kurt, G., Çamlibel, Z., Ersin, P., \& Kaslioglu, Ö. (2009). The Role of Intercultural Competence in Foreign Language Teaching. Inonu University Journal of the Faculty of Education (INUJFE), 10(3) https://dergipark.org.tr/tr/pub/inuefd/issue/8704/108680

Ayora Esteban, C. (2017). La Competencia Sociolingüística y los Componentes Culturales dentro del Proceso de Enseñanza- Aprendizaje del Español en un Contexto de Submersión Lingüística. Pragmalingüística, 25, 31-49. https://revistas.uca.es/index.php/pragma/article/view/3667/3759

Bal, N. G., \& Savas, P. (2020). Intercultural Competence in the Eyes of State School English Language Teachers in Turkey. Journal of Language and Education, 6(2), 56-75.

Byram, M. (1997). Teaching and assessing intercultural communicative competence. Multilingual Matters.

Byram, M. (2015). Culture in Foreign Language Learning-The Implications for Teachers and Teacher Training. In W. Meng Chan, S. Kumar Bhatt, M. Nagami, \& I. Walker (Eds.), Culture and Foreign Language Education: insights from research and implications for the practice (p. 38). De Gruyter Mouton.

Canga Alonso, A. (2020) Fostering the Teaching of Cultural Vocabulary in EFL Contexts. In M. Dodigovic M. P. Agustín-Llach (Eds), Vocabulary in Curriculum Planning. Palgrave Macmillan, Cham. https://doi.org/10.1007/978-3-030-48663-1_10

Casey, H. (2017). Big Questions 6 (Class Book). Oxford University Press.

Cheewasukthaworn, K., \& Suwanarak. K. (2017). Exploring Thai EFL Teachers' Perceptions of how Intercultural Communicative Competence is Important for their Students. PASAA: Journal of Language Teaching and Learning in Thailand, 54, 177-204. https://files.eric.ed.gov/fulltext/EJ1171209.pdf

Chomsky, N. (1965). Aspects of the theory of syntax. MIT Press

Clouet, R. (2012). Studying the Role of Intercultural Competence in Language Teaching in Upper Secondary Education in the Canary Islands, Spain. Onomázein: Revista de lingüistica, filología y traducción, 26 (2), 309-334. http://onomazein.letras.uc.cl/Articulos/26/11_Clouet.pdf

Council of Europe. Council for Cultural Co-operation. Education Committee. Modern Languages Division. (2001). Common European Framework of Reference for Languages: Learning, teaching, assessment. Cambridge University Press. https://rm.coe.int/16802fc1bf

Council of Europe. (2020). Common European Framework of Reference for Languages: Learning, teaching, assessment - Companion Volume. https://rm.coe.int/cefr-companion-volume-with-new-descriptors2018/1680787989

Decreto $\mathrm{N}^{\circ}$ 24. Boletín Oficial de La Rioja (BOR), Logroño, La Rioja, España, July 16, 2014. https://web.larioja.org/normativa?n=1973

Demircioğlu, Ş., \& Çakır, C. (2015). Intercultural Competence of English Language Teachers in International Baccalaureate World Schools in Turkey and abroad. Journal of language and linguistic studies, 11(1), 15-32. https://www.jlls.org/index.php/jlls/article/view/334

Galindo-Merino, M. M. (2005). La Importancia de la Competencia Sociocultural en el Aprendizaje de Segundas Lenguas. Interlingüística, 16 (1), 431-441.

Guryanov, I. O., Rakhimova, A. E., \& Guzman, M. C. (2019). Socio-Cultural Competence in Teaching Foreign Languages. International Journal of Higher Education, 8(7), 116-120.

House, S. (2011). INGLÉS: Complementos de Formación Disciplinar. GRAÓ

Hymes, D. (1971). Foundations in Sociolinguistics: an Ethnographic Approach, Volume 6 (Reprinted in 2001 by Routledge) London. International Journal of Cross Cultural Management.

Kramsch, C., \& Zhu, H. (2016). Language and Culture in ELT. The Routledge handbook of English language teaching, 38-50.

Martínez Iglesias M. I. (2009) Estrategia Didáctica para Desarrollar la Competencia Sociolingüística en los Alumnos de los cursos Preparatorios de Español como Lengua Extranjera. Recurso electrónico. http://www. eumed. net/tesisdoctorales/2009/mimi/enfoque $\% \quad 20$ comunicativo $\% \quad 20 \mathrm{y} \% \quad 201 \mathrm{la} \%$ 20ensenanza\% 20de\% 20lenguas\% 20extranjeras. htm.

Méndez García, M. D. C., Castro Prieto, P., \& Sercu, L. (2005 - 2006). La Construcción del Aprendizaje Cultural: Análisis de las Percepciones del Profesorado de Inglés. ELIA, 6, 151-172. http://institucional.us.es/revistas/elia/6/art.8.pdf 
Méndez García, M. D. C., Castro Prieto, P., \& Sercu, L. (2003). Contextualising the Foreign Language. An Investigation of the Extent of Teachers' Sociocultural Background Knowledge. Journal of multilingual and multicultural development, 24(6), 496-512. https://doi.org/10.1080/01434630308666513

Neuner, G. (1996). The Role of Sociocultural Competence in Foreign Language Teaching and Learning. Language Teaching, 29(4), 234-239. https://doi.org/10.1017/S0261444800008545

Pérez García, E., Gómez Parra, M. E. \& Serrano Rodríguez, R. (2017). CLIL Teachers’ Perceptions of Intercultural Competence in Primary Education [Percepciones del profesorado AICLE sobre la competencia intercultural en Educación Primaria]. Revista Digital de Investigación en Docencia Universitaria, 11 (1), 82-99. http://dx.doi.org/10.19083/ridu.11.497

Read, C. \& Ormerod, M. (2018). New Tiger 6. Macmillan.

Richards, J. \& Schmidt, R. (2010). Culture. In Longman. Dictionary of Language Teaching and Applied Linguistics (4th ed., p.151).

van Ek, J.A. (1986) Objectives for Foreign Language Learning. Council of Europe.

Vetrinskaya, V. V., \& Dmitrenko, T. A. (2017). Developing Students' Sociocultural Competence in Foreign Language Classes. Training language and culture, 1(2), 23-41.

Young, T. J., \& Sachdev, I. (2011). Intercultural Communicative Competence: Exploring English Language Teachers' Beliefs and Practices. Language awareness, 20(2), 81-98. https://doi.org/10.1080/09658416.2010.540328 


\section{Appendices}

\section{Appendix 1. Questionnaire sections}

Some questions remain the same (S) as in Méndez García et al. (2005-06)'s study, others are transformed (T) and some new others were added $(\mathrm{N})$.

\section{$1^{a}$ parte: Actitudes de los estudiantes hacia las lenguas y culturas extranjeras.}

Contesta nunca, rara vez, a veces, casi siempre, siempre.

1. Mis estudiantes piensan que aprender la lengua extranjera es difícil (S).

2. Mis estudiantes están motivados para aprender la lengua extranjera (S).

3. Mis estudiantes piensan que aprender la lengua extranjera es útil $(\mathrm{N})$

4. Mis estudiantes tienen conocimiento sobre la cultura de la lengua extranjera (S).

5. Mis estudiantes tienen una actitud positiva hacia los miembros de la cultura extranjera (S).

6. Mis estudiantes se muestran atraídos y curiosos por la cultura extranjera $(\mathrm{N})$.

7. Mis estudiantes muestran iniciativa por aprender la lengua extranjera $(\mathrm{N})$.

8. Mis estudiantes parten de concepciones prefijadas y estereotipos sobre la cultura extranjera de los medios de comunicación (N).

9. En líneas generales, la percepción que tienen mis estudiantes de la(s) cultura(s) asociada(s) a la lengua extrajera son: (positivas/negativas) $(\mathrm{N})$.

10. Las ideas positivas que tienen mis estudiantes de los países y de las gentes extranjeras proceden del ámbito del aula $(\mathrm{N})$.

11. Las ideas negativas que tienen de los países y de las gentes extranjeras vienen de fuera del ámbito de la clase: películas, cine, etc. (S)

12. Mis estudiantes sienten rechazo hacia tradiciones y costumbres diferentes $(\mathrm{S})$.

13. En general, mis estudiantes tienen ideas positivas acerca del país extranjero (T).

14. En general, mis estudiantes no saben distinguir la heterogeneidad del mundo de habla inglesa (por ejemplo, Estados Unidos y el Reino Unido) (S).

15. Pienso que mis estudiantes se sienten más atraídos por Estados Unidos (S).

16. Pienso que mis estudiantes se muestran más atraídos por Reino Unido (T).

17. Mis estudiantes frecuentemente hablan sobre países de habla inglesa diferentes a Reino Unido y Estados Unidos (N).

18. En general, mis estudiantes tienen ideas receptivas y muestran gran interés en todo lo relacionado con la gente y culturas de otros países $(\mathrm{N})$.

19. Mis estudiantes ven la lengua extranjera como un medio para relacionarse con gente de otras culturas $(\mathrm{N})$.

\section{$2^{\text {a }}$ parte: Inclusión de la cultura en la práctica docente}

1. ¿Con qué frecuencia incluyes los siguientes temas en tu práctica docente? Nunca, rara vez, a veces, casi siempre, siempre $(\mathrm{T})$

- Vida diaria y rutinas

- Gastronomía

- Folklore y tradiciones

- Turismo y ocio

- Literatura

- Educación

- Historia, geografía 
- $\quad$ Política y sociedad

- Artes

- $\quad$ Creencias y valores

- $\quad$ Grupos étnicos y sociales diferentes

\section{Contesta nunca, rara vez, a veces, casi siempre, siempre}

2. Comento mis propias experiencias en la cultura extranjera (S).

3. Comento lo que he oído (o leído) sobre la cultura o del país/países donde se habla la lengua extranjera (S).

4. Los estudiantes comparan un aspecto de su propia cultura con el correspondiente en la cultura extranjera (S).

5. Comento aspectos que me parecen más destacables de la cultura/s de la lengua/s extranjera/s (S).

6. Hago referencia a aspectos culturales representados en los materiales (S).

7. Trato de utilizar recursos multimedia que ilustren ciertos aspectos de la cultura/s de la lengua extranjera $(\mathrm{T})$.

8. Cuando tengo oportunidad, trato de presentar a mis estudiantes de primera mano a personas de países extranjeros o les llevo objetos propios de la cultura extranjera (T).

9. Comentamos los estereotipos sobre la cultura/s ligada/s a la lengua/s extranjera/s (S).

10. Se trabajan actividades interactivas en las que se reproducen situaciones interculturales; es decir, imitando situaciones reales $(\mathrm{T})$.

11. Mis estudiantes se imaginan cómo podría ser vivir en otra cultura (S).

12. Mis estudiantes describen algún aspecto de su propia cultura en la lengua extranjera $(\mathrm{N})$.

13. Animo a mis estudiantes a que compartan sus experiencias personales y conocimientos sobre la cultura extranjera (S).

14. ¿Con qué frecuencia pregunto a mis estudiantes si hay algo de la cultura o de la lengua extranjera que utilicen en su tiempo de ocio? (N)

- Vídeos

- Canciones

- Videojuegos

- $\quad$ Redes sociales

15. Decoro la clase con posters para ilustrar aspectos de la cultura extranjera (S).

16. Intento establecer relaciones entre los aspectos culturales de la L1 de mis estudiantes con los de las distintas culturas de los países anglófonos $(\mathrm{N})$.

17. Trato de introducir palabras que se refieran a realidades inexistentes en la L1, pero que sí que existen en la L2 (como, por ejemplo, haggis (comida típica escocesa) $(\mathrm{N})$.

18. Hago referencia a las distintas variedades del inglés como lengua internacional y/o lengua cooficial (por ejemplo: India) $(\mathrm{N})$.

19. Trato de que mis estudiantes entiendan la diversidad, y a las personas pertenecientes a otras culturas $(\mathrm{N})$.

20. Presento los aspectos culturales de la lengua extranjera de forma paralela al resto de los contenidos curriculares $(\mathrm{N})$.

21. Trato de integrar los rasgos culturales dentro de mi práctica docente $(\mathrm{N})$.

22. Animo a mis estudiantes para que busquen información por su cuenta sobre la cultura/s de la lengua/s extranjeras $(\mathrm{N})$. 
23. Evito presentar en clase opiniones (negativas) sobre determinados rasgos de la cultura extranjera que no comparto ( $\mathrm{T}$ ).

$3^{\text {a }}$ parte: percepciones de los profesores sobre la enseñanza de la lengua y cultura extranjera.

1. ¿Qué consecuencias tiene para ti la inclusión de los aspectos culturales en las clases de lengua extranjera? (N)

2. ¿Qué limitaciones ves a la hora de incluir la cultura extranjera en tu práctica docente? $(\mathrm{N})$

3. ¿Qué aspectos culturales crees que son más fáciles de enseñar dentro del aula? (N)

4. ¿Qué tipo de datos de actualidad relacionados con la cultura/s de la lengua/s extranjera/s intentas trasladar al aula? $(\mathrm{N})$

5. ¿Cambiarías algún aspecto del currículo en relación con el tiempo dedicado a la cultura/s extranjera/s en el aula? En caso afirmativo, ¿cuáles? (N) 